\title{
Front Matter: Volume 11659
}

, "Front Matter: Volume 11659," Proc. SPIE 11659, Colloidal Nanoparticles for Biomedical Applications XVI, 1165901 (22 April 2021); doi:

10.1117/12.2596759

SPIE. Event: SPIE BiOS, 2021, Online Only 


\title{
PROG RESS IN BIOMEDICAL OPTICS AND IMAG ING
}

\section{Colloidal Nanopartic les for Biomedical Applications XVI}

\author{
Marek Osiński \\ Antonios G. Kanaras \\ Editors
}

\section{6-11 March 2021 \\ Online Only, United States}

Sponsored by

SPIE

Cosponsored by

Ocean Optics, Inc. (United Sta tes)

Published by

SPIE 
The papers in this volume were part of the technical conference cited on the cover and title page. Papers were selected and subject to review by the editors and conference program committee. Some conference presentations may not be available for publication. Additional papers and presentation recordings may be available online in the SPIE Digital Library at SPIEDigitalLibrary.org.

The papers reflect the work and thoughts of the authors and are published herein as submitted. The publisher is not responsible for the validity of the information or for any outcomes resulting from reliance thereon.

Please use the following format to cite material from these proceedings:

Author(s), "Title of Paper," in Colloidal Nanoparticles for Biomedical Applications XVI, edited by Marek Osiński, Antonios G. Kanaras, Proceedings of SPIE Vol. 11659 (SPIE, Bellingham, WA, 2021) Seven-digit Article CID Number.

ISSN: 1605-7422

ISSN: 2410-9045 (electronic)

ISBN: 9781510641532

ISBN: 9781510641549 (electronic)

Published by

SPIE

P.O. Box 10, Bellingham, Washington 98227-0010 USA

Telephone +1 3606763290 (Pacific Time) · Fax +1 3606471445

SPIE.org

Copyright (c) 2021, Society of Photo-Optical Instrumentation Engineers.

Copying of material in this book for internal or personal use, or for the internal or personal use of specific clients, beyond the fair use provisions granted by the U.S. Copyright Law is authorized by SPIE subject to payment of copying fees. The Transactional Reporting Service base fee for this volume is $\$ 21.00$ per article (or portion thereof), which should be paid directly to the Copyright Clearance Center (CCC), 222 Rosewood Drive, Danvers, MA 01923. Payment may also be made electronically through CCC Online at copyright.com. Other copying for republication, resale, advertising or promotion, or any form of systematic or multiple reproduction of any material in this book is prohibited except with permission in writing from the publisher. The CCC fee code is $1605-$ $7422 / 21 / \$ 21.00$.

Printed in the United States of America by Curran Associates, Inc., under license from SPIE.

Publication of record for individual papers is online in the SPIE Digital Library.

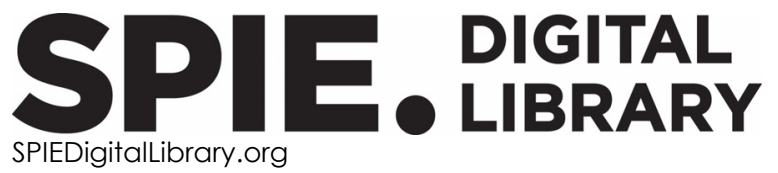

Paper Numbering: Proceedings of SPIE follow an e-First publication model. A unique citation identifier (CID) number is assigned to each article at the time of publication. Utilization of CIDs allows articles to be fully citable as soon as they are published online, and connects the same identifier to all online and print versions of the publication. SPIE uses a seven-digit CID article numbering system structured as follows:

- The first five digits correspond to the SPIE volume number.

- The last two digits indicate publication order within the volume using a Base 36 numbering system employing both numerals and letters. These two-number sets start with $00,01,02,03,04$, 05, 06, 07, 08, 09, 0A, OB ... 0Z, followed by 10-1Z, 20-2Z, etc. The CID Number appears on each page of the manuscript. 


\section{Contents}

BIOMEDICALAPPUCATIONSOF NANOMATERIALS I

$1165905 \quad$ Gold nanopartic les for tumor detection with proton radiography: optimizing sensitivity and determining detection limits [11659-3]

1165906 Developing a novel biodegradable nanodrug platform for overcoming the challenges in treating pancreatic ductal adenocarcinoma (PDAC) [11659-4]

IMAGING WTH NANOMATERIALS I

11659 OC Surface chemistry-mediated metal nanoclusters for in vivo shortwave infrared imaging (Invited Paper) [11659-14]

NANOMATERIALS SYNTHESIS AND FUNCTIONAUZATION I

11659 ON Synthesis of colloidal SeTe nanoalloy by pulsed laser ablation in deep eutec tic solvents to be used as antic ancer treatment [11659-25]

NANOMATERIALS SYNTHESIS AND FUNCTIONAUZATION II

$116590 \mathrm{G}$ Green synthesis of gold nanoparticles and their deposition on mo surfaces [11659-28]

DNA NANOMATERIALS

1165910 DNA origami and DNA onigami silica hybrids for biomedical applications (Invited Paper) [11659-9]

1165913 Themal stabilization of nucleic acid nanoparticles (NANPS) using light-assisted drying [11659-12] 
Proc. of SPIE Vol. 11659 1165901-4

\section{Downloaded From: https://www.spiedigitallibrary.org/conference-proceedings-of-spie on 25 Apr 2023
Terms of Use: https://www.spiedigitallibrary.org/terms-of-use}

